\title{
APLIKASI GAME SIMULATION UNTUK MEREDUKSI KECEMASAN SISWA DALAM MENGHADAPI UN KELAS IX SMP NEGERI I DAGANGAN
}

\author{
Hagus Muryanto, Asroful Kadafi, Rischa Pramudia Trisnani \\ Vivi Yuniar Fitriani.
}

\begin{abstract}
Abstrak
Keberhasilan Ujian Nasional salah satunya ditentukan oleh kondisi psikis para siswa. Perasaan takut gagal dapat menjadi beban yang menyebabkan para siswa memiliki kecemasan dalam menghadapi ujian nasional. Kecemasan ini dapat mempengaruhi kondisi psikologis mereka yang akan mengganggu aktivitas mereka sebagai reaksi terhadap adanya sesuatu yang bersifat mengancam. Ketenangan dalam menghadapi ujian nasional mutlak diperlukan bagi peserta ujian nasional. Diharapkan dalam menghadapi ujian nasional siswa dalam kondisi tenang

Berdasar observasi yang dilakukan oleh peneliti, dari Jumlah total Kelas IX SMP Negeri 1 Dagangan ada 245 siswa dan hanya 25\% yang tidak mengalami kecemasan menghadapi UN. Sesuai dengan permasalahan yang diteliti dan prosedur yang ditempuh, penelitian ini menggunakan desain True-Experimental. Sampel penelitian ditetapkan secara acak yang keseluruhannya berjumlah 40 siswa SMP Negeri I Dagangan Madiun dengan perincian 20 siswa untuk kelompok yang diberi perlakuan game simulation untuk mereduksi kecemasan dalam mengahadapi UN dan 20 siswa untuk kelompok yang tidak diberi perlakuan game simulation untuk mereduksi kecemasan dalam mengahadapi UN.

Pelaksanaan eksperimental berlangsung selama 10 kali 45 menit di lapangan. Data yang berhasil dikumpulkan melalui test, dianalisis dengan t-test. Hasil analisis data menunjukkan bahwa penelitian mengenai perbedaan kecemasan siswa dalam menghadapi UN antara yang diberi perlakuan dengan game simulation dan yang tidak diberi perlakuan game simualtion dalam taraf kepercayaan $95 \%$ terbukti secara signifikan. Begitu pula pada taraf kepercayaan $99 \%$ terbukti ada perbedaan yang signifikan.

Berdasar perhitungan t-score diketahui ada perbedaan sebesar rata-rata 6,44 antara kedua kelompok tersebut. Hal ini menunjukkan bahwa game simulation berpengaruh positif dalam mereduksi kecemasan siswa dalam menghadapi UN, baik dalam taraf $95 \%$ maupun $99 \%$.
\end{abstract}

Kata Kunci: Kecemasan, Game Simulation

* Hagus Muryanto, Asroful Kadafi, Rischa Pramudia Trisnani dan Vivi Yuniar Fitriani adalah Dosen Program Studi Bimbingan dan Konseling Fakultas Ilmu Pendidikan IKIP PGRI Madiun. 


\section{Pendahuluan}

Ujian Nasional (UN) merupakan kebijakan yang telah ditetapkan oleh pemerintah (Permendiknas Nomor 34 tahun 2007) untuk mengukur kompetensi lulusan. Secara umum, UN diselenggarakan untuk meningkatkan kualitas Sumber Daya Manusia (SDM). Bercermin kepada negara lain, pendidikan menjadi penentu tinggi rendahnya standar kualitas manusia. Kualitas SDM yang tinggi menjadi modal bagi pembangunan nasional dan menjadi comparative advantage dalam dunia yang semakin kompetitif.

Namun pada kenyataannya, pelaksanaan UN banyak menuai kontroversi karena ujian nasional seringkali ditanggapi sebagai beban oleh para siswa. Siswa menyiapkan diri baik fisik maupun non fisik agar mereka terhindar dari kegagalan dalam ujian nasional. Kegagalan dalam ujian nasional berdampak, siswa akan merasa memikul beban moral seperti rasa malu, canggung, minder dan menghindari pergaulan yang pada akhirnya mereka akan kehilangan rasa percaya diri. Perasaan takut gagal tersebut dapat menjadi beban yang menyebabkan para siswa memiliki kecemasan dalam menghadapi ujian nasional. Kecemasan ini dapat mempengaruhi kondisi psikologis mereka yang akan mengganggu aktivitas mereka sebagai reaksi terhadap adanya sesuatu yang bersifat mengancam. Ketenangan dalam menghadapi ujian nasional mutlak diperlukan bagi peserta ujian nasional.

Upaya yang dilakukan untuk mereduksi kecemasan yang dirasakan oleh para siswa di SMP Negeri 1 Dagangan ini adalah dengan mengadakan try out dan memaksa para siswa dan guru untuk disiplin belajar yang sebenarnya malah menambah rasa kecemasan akan kegagalan hasil yang diperoleh karena otak diforsir untuk terus belajar. Upaya yang dilakukan oleh pihak sekolah masih belum dapat mereduksi kecemasan yang dialami oleh para siswa.

Bagi para siswa pelaksanaan UN dirasakan sebagai beban yang semakin bertambah berat, salah satunya adalah dengan adanya peningkatan angka Standar Kompetensi Lulusan Ujian Nasional (SKLUN) yang terjadi terus menerus. Tidak heran jika banyak siswa yang berusaha keras untuk bisa lulus UN dengan melakukan berbagai persiapan, baik mengikuti les tambahan atau bimbingan belajar di luar sekolah untuk mendalami materi (pelajaran) yang nantinya akan diujikan dalam UN, maupun berbagai persiapan mental yang dilakukan melalui pendekatan spiritual (doa bersama dan istigosah), agar siap dan sukses dalam UN.

Dengan melihat berbagai upaya yang dilakukan siswa dan sekolah dalam mempersiapkan UN, dapat diketahui bahwa penyelenggaraan UN memang menjadi sebuah fenomena yang dapat memunculkan perasaan khawatir, takut serta tertekan pada diri siswa, sehingga berbagai upaya pun dicoba untuk dilakukan agar dapat meminimalisir perasaan-perasaan yang tidak menyenangkan tersebut, sehingga siswa siap menghadapi UN. Perasaan tertekan, khawatir, dan 
takut akan kegagalan, yang dirasakan siswa saat dalam tahap mempersiapkan UN tersebut disebut sebagai kecemasan menghadapi UN. Kecemasan atau anxiety merupakan salah satu bentuk emosi individu yang berkenaan dengan adanya rasa terancam oleh sesuatu, biasanya dengan objek ancaman yang tidak begitu jelas.

Keberhasilan ujian nasional salah satunya ditentukan oleh kondisi psikis para siswa. Diharapkan dalam menghadapi ujian nasional siswa dalam kondisi tenang. Dengan berkurangnya kecemasan para siswa, maka mereka diharapkan lebih siap dalam menghadapi ujian nasional. Untuk mereduksi kecemasan yang dialami oleh siswa peneliti berusaha mengaplikasikan game simulation. Game simulation ini digunakan sebagai media untuk relaksasi guna mengurangi kecemasan dan ketegangan dengan pertimbangan bahwa pemberian game simulation mudah, murah, dan tidak membebani para siswa. Game berasal dari kata bahasa Inggris yang berarti dasar permainan. Permainan dalam hal ini merujuk pada pengertian kelincahan intelektual (Intellectual Playability Game) yang juga bisa diartikan sebagai arena keputusan dan aksi pemainnya. Jenis ini bertujuan untuk memberi pengalaman melalui simulasi construction and manajement simulation game adalah tipe game simulasi dimana player harus mendirikan, memperluas atau mengelola komunitas atau proyek fiksi.

Dengan mengaplikasikan game simulation ini dipandang sesuai untuk mereduksi kecemasan yang dialami oleh para siswa yang akan menghadapi UN. Dengan mengaplikasikan game simulation diharapkan siswa mampu merefleksi otak yang menimbulkan munculnya kecemasan karena game bertujuan untuk menghibur. Games sebenarnya juga penting untuk perkembangan otak, untuk meningkatkan konsentrasi dan melatih untuk memecahkan masalah dengan tepat dan cepat karena dalam game terdapat berbagai konflik atau masalah yang menuntut kita untuk menyelesaikannya dengan cepat dan tepat. Hal lain yang mendukung penelitian ini adalah belum adanya penelitian sejenis yang mengkaji masalah tersebut, sehingga peneliti memandang topik ini layak dan perlu untuk direalisasikan, maka peneliti akan melakukan penelitian dengan judul "Aplikasi Game Simulation untuk Mereduksi Kecemasan dalam Menghadapi UN Siswa Kelas IX SMP Negeri 1 Dagangan"

Berdasarkan latar belakang di atas, maka dalam penelitian ini dapat dikemukakan rumusan masalah sebagai berikut: "Apakah dengan aplikasi game simulation efektif digunakan untuk mereduksi kecemasan dalam menghadapi UN siswa Kelas IX SMP Negeri 1 Dagangan".

Pada hakikatnya tujuan penelitian ini adalah mengaplikasikan game simulation untuk mereduksi kecemasan siswa Kelas IX SMP Negeri 1 Dagangan.

Kecemasan didefinisikan sebagai gangguan kemurungan (melancholic disorder) yang disebabkan karena terlalu banyak perasan murung (Ramaiah, 2003: 111). Pada sisi lain, kecemasan merupakan hasil pikiran tidak nyaman yang 
bereaksi terhadap keadaan yang kelihatannya negatif bagi seseorang tetapi tidak mengancam secara terbuka (Ramaiah, 2003: 81).

Anxietas/kecemasan (anxiety) adalah suatu keadaan aprehensi atau keadaan khawatir yang mengeluhkan bahwa sesuatu yang buruk akan segera terjadi (dalam Jeffrey S.Nevid 2003:163).

Menurut Sutardjo (2005:69), gangguan anxiety merupakan suatu gangguan yang memiliki cirri kecemasan atau ketakutan yang tidak realistic, juga irrasional, dan tidak dapat secara intensif ditampilkan dalam cara-cara yang jelas

Dari berbagai pengertian diatas, dapat disimpulkan bahwa kecemasan merupakan kondisi psikologis yang merupakan reaksi terhadap situasi menekan dengan ditandai perasaan ketakutan, ketegangan, kekhawatiran, dan kegelisahan baik disadari maupun tidak disadari.

Adanya berbagai factor yang menimbulkan perasaan cemas atau takut itu, menimbulkan suatu perasaan yang berbahaya, yang tidak selalu jelas apa penyebabnya. Dalam teori freud (dalam Sutardjo 2007:68) kecemasan ditemukan dalam tiga jenis, yaitu :

a. Kecemasan yang sumbernya obyektif/kecemasan nyata, yang juga disebut takut (feat).

b. Kecemasan yang disebut kecemasan neurotic, yaitu kecemasan yang tidak memperlihatkan sebab dan ciri-ciri khas yang obyektif.

c. Kecemasan sebagai akibat dari adanya keinginan yang tertahan oleh hati nurani (conscience)

Berdasarkan uraian di atas dapat disimpulkan bahwa jenis kecemasan yaitu: kecemasan yang timbul dapat dilihat dari sumber obyektif/kecemasan nyata, kecemasan neurotic, dan kecemasan yang tertahan oleh hati nurani.

Faktor-faktor penyebab timbulnya kecemasan menurut Nevid, dkk (2003:196) dipengaruhi beberapa faktor, yaitu:

a. Faktor sosial lingkungan

Meliputi pemaparan terhadap peristiwa yang mengancam atau traumatis, mengamati respon takut pada orang lain, dan kurangnya dukungan sosial.

b. Faktor biologis

Meliputi predisposisi genetis, ireguaritas dalam fungsi neurotransmiter, dan abnormalitas dalam jalur otak yang memberi sinyal bahaya atau yang menghambat tingkah laku repetitif.

c. Faktor behavioral

Meliputi pemasangan stimuli aversif dan stimuli yang sebelumnya netral, kelegaan dari kecemasan karena melakukan ritual kompulsif atau menghindari stimuli fobik, dan kurangnya kesempatan untuk pemunahan karena penghindaran terhadap objek atau situasi yang ditakuti.

d. Faktor kognitif dan emosional 
Meliputi konflik psikologis yang tidak terselesaikan (Freudian atau teori psikodinamika), faktor-faktor kognitif seperti prediksi berlebihan tentang ketakutan, keyakinan-keyakinan yang self defeating atau irasional, sensivitas berlebih terhadap ancaman, sensivitas kecemasan, salah atribusi dari sinyal-sinyal tubuh, dan self efficacy yang rendah. Berdasarkan uraian di atas maka dapat diketahui bahwa faktor-faktor penyebab timbulnya kecemasan adalah faktor sosial lingkungan, faktor biologis, faktor behavioral, dan faktor kognitif dan emosional.

Menurut Denny (2012:1) tingkat kecemasan manusia dapat digolongkan pada empat tingkatan kecemasan, yaitu:

a. Kecemasan ringan

Kecemasan ringan berhubungan dengan ketegangan dalam kehidupan sehari-hari dan menyebabkan seseorang menjadi waspada dan meningkatkan lahan persepsinya. Kecemasan ringan dapat memotivasi belajar dan menghasilkan pertumbuhan dan kreatifitas.

b. Kecemasan sedang

Memungkinkan seseorang untuk memusatkan pada masalah yang penting dan mengesampingkan yang lain sehingga seseorang mengalami perhatian yang selektif, namun dapat melakukan sesuatu yang terarah.

c. Kecemasan berat

Sangat mengurangi lahan persepsi seseorang. Seseorang dengan kecemasan berat cenderung untuk memusatkan pada sesuatu yang terinci dan spesifik, serta tidak dapat berpikir tentang hal lain. Orang tersebut memerlukan banyak pengarahan untuk dapat memusatkan pada suatu area yang lain.

d. Panik

Panik berhubungan dengan terperangah, ketakutan dan teror karena mengalami kehilangan kendali. Orang yang sedang panik tidak mampu melakukan sesuatu walaupun dengan pengarahan. Tanda dan gejala yang terjadi pada keadaan ini adalah susah bernapas, dilatasi pupil, palpitasi, pucat, diaphoresis, pembicaraan inkoheren, tidak dapat berespon terhadap perintah yang sederhana, berteriak, menjerit, mengalami halusinasi dan delusi.

Berdasarkan uraian di atas dapat disimpulkan bahwa tingkat kecemasan ada yang ringan, sedang, berat bahkan kecemasan pada tingkat kepanikan.

\section{Game Simulation (Permainan Simulasi)}

Secara umum bermain dapat diartikan sebagai suatu aktifitas yang menyenangkan, ringan, bersifat kompetitif atau kedua-duanya. Permainan dilakukan baik oleh anak-anak maupun orang dewasa. Dengan bermain, anakanak dapat mengenal lingkungannya, belajar tentang aturan-aturan masyarakat, 
menirukan dan menemukan pikiran-pikiran dan hubungan-hubungan yang berarti. Dengan cara ini anak-anak dapat belajar berbagai macam pengetahuan yang memungkinkan mereka untuk dapat bergaul dan hidup di masyarakat. Jadi, permainan dapat disebut sebagai alat untuk mengembangkan pengenalan terhadap llingkungan. Dengan demikian bermain merupakan cara belajar yang menyenangkan, karena dengan bermain anak-anak belajar sesuatu tanpa mempelajarinya. Apa yang dipelajari ini disimpan dalam pikirannya dan akan dipadukan menjadi satu kesatuan dengan pengalaman-pengalaman lain yang kadang tanpa disadarinya.

Permainan simulasi seperti juga permainan yang lain mempunyai batas waktu dan aturan-aturan tertentu yang agak membatasi kebebasan pemain. Menurut adam (dalam Romlah: 2006) permainan simulasi adalah permainan yang dimaksudkan untuk merefleksikan situasi-situasi yang terdapat dalam kehidupan sebenarnya. Tetapi situasi itu hampir sebagian atau dikeluarkan dari konteksnya. Dalam hal ini perlu diperhatikan bahwa situasi yang disimulasikan hendaknya tidak terlalu kompleks dan tidak terlalu sederhana. Apabila terlalu kompleks para pemain menjadi kurang bereani memainkannya, sebaliknya apabila terlalu mudah mereka akan cepat bosan. Meskipun demikian, permainan simulasi tetap dapat menyediakan suatu gambaran kehidupan dan kenyataan yang berarti.

Permainan simulasi dibuat untuk tujuan tertentu, misalnya membantu siswa untuk mempelajari pengalaman-pengalaman yang berkaitan dengan aturan sosial.

Dalam hal ini peserta permainan dapat memerankan peran yang sama sekali asing baginya. Permainan simulasi hampir sama dengan permainan peranan tetapi dalam permainan simulasi kadang-kadang pemain menghalangi pemain lainnya.

Permainan simulasi dapat dikatakan sebagai gabungan antara teknik bermain peranan dengan teknik diskusi. Dalam permainan simulasi para pemainnya berkelompok dan berkompetisi untuk mencapai tujuan-tujuan tertentu dengan mentaati peraturan-peraturan yang ditetapkan bersama. Dalam permainan tersebut para pemain harus berperan dan berperilaku seperti jika mereka benarbenar terlibat dalam situasi kehidupan yang sebenarnya. Jumlah pemain dalam permaianan simulasi terbatas, dan lama pernainannya juga terbatas. Selain itu permainan simulasi membutuhkan tempat dan peralatan tertentu.

Topik-topik permainan simulasi disesuaikan dengan tingkat perkembangan dan latar belakang lingkungan anak, dengan demikian mereka tidak merasa melakukan sesuatu yang tidak mereka sukai. Permainan simulasi cocok untuk memotivasi anak belajar, terutama bila bahan pelajaran yang dipelajarinya kurang menarik. Permainan simulasi selain berguna untuk memperkenalkan konsep dan menanamkan pengertian tentang suatu hal, juga mempunyai kekuatan untuk membangkitkan minat dan perhatian anak.(Romlah, 2006:119) 
Penggunaan teknik permainan simulasi baik untuk kepentingan pengajaran maupun bimbingan didasarkan pada pikiran-pikiran bahwa belajar secara berarti dapat terjadi apabila si belajar menyatu dan akrab dengan lingkungan belajarnya. Dalam konteks ini anak belajar dari pengalaman dengan lingkungan belajar dan mengintegrasikan apa yang dipelajarinya dengan apa yang diperolehnya dengan cara demikian akan lebih dapat meresap dan terus mengalir lama.

Untuk membuat permainan simulasi dapat diikuti langkah-langkah sebagai berikut (Romlah, 2006:119):

a. Meneliti msalah yang banyak dialami anak, terutama menyangkut dalam bidang pendidikan dan sosial

b. Merumuskan tujuan yang ingin dicapai dengan permainan itu. Dalam melakukan hal ini anggota kelompok atau siswa supaya diikutsertakan.

c. Membuat daftar sumber-sumber yang dapat dipakai untuk membantu menyelesaikan topik yang akan digarap, misalnya alat-alat yang diperlukan, buku sumber, dan waktu yang sesuai untuk mengerjakan tugas antara konselor dan siswa

d. Memilih situasi dalam kehidupan sebenarnya yang ada kaitannya dengan kehidupan siswa. Pelajari struktur situasi tersebut, dan aturan-aturan yang mengatur perilaku mana yang dibolehkan dan perilaku mana yang tidak dilakukan.

e. Membuat skenario atau model dari situasi yang sudah dipilih

f. Identifikasi siapa saja dan berapa orang yang akan terlibat dalam permainan ini.

g. Membuat alat-alat permainan simulasi, misalnya beberan, kartu pesan, kartu yang berisi kegiatan yang harus dilakukan untuk mengisi kegiatan selingan dan sebagainya.

Setelah semua langkah tersebut dikerjakan, pemimpin kelompok bersamasama dengan anggota kelompok membuat aturan-aturan-aturan dasar dalam memainkan permainan simulasi. Setelah semuanya selesai, permainan dicoba untuk dimainkan untuk melihat apakah pesan-pesan yang dibuat sudah cukup komunikatif dan dapat dipahami oleh orang lain. Pesan-pesan yang tidak jelas kemudian diperbaiki dan dicobakan kembali. Keseluruhan perlengkapan permainan simulasi yang siap dimainkan terdiri dari:

a. Lembaran permainan, yang memuat pesan-pesan dan gambar-gambar yang sesuai dengan topik permainan

b. Kartu-kartu pesan, yang berisi pesan-pesan yang tidak dipaparkan dalam lembaran permainan. Kartu-kartu ini dapat diberi tanda khusus misalnya bintang, bendera, gambar bua-buahan atau gambar lainnya.

c. Alat penentu langkah, dapat berupa dadu, kubus yang bertuliskan angka 1, 2, 3, 4, 5 atau kartu yang berisi angka 1-6, atau gulungan kertas (lot) yang 
bertuliskan angka 1-6. Tanda untuk bermain bagi masing-masing pemain dapat berupa segi empat dari kertas manila, atau benda-benda lain misalnya kancing baju, uang logam, dan lain-lain.

\section{Cara Melaksanakan Permainan Simulasi}

Langkah pertama yang perlu dilakukan dalam memainkan permainan simulasi adalah menentukan peserta permainan. Peserta permainan adalah mereka yang terlibat dalam permainan simulasi yang terdiri dari:

Fasilitator, individu yang bertugas memimpin permainan simulasi. Tugas fasilitator adalah menjelaskan tujuan permainan, mendorong pemain dan penonton untuk aktif ikut berdiskusi, membantu memecahkan masalah yang timbul selama permainan, menjawab pertanyaan yang tak dapat dijawab oleh peserta lain, mengarahkan diskusi dan melaporkan hasilnya.

a. Penulis, bertugas mencatat segala sesuatu yang terjadi selama permainan berlangsung

b. Pemain, individu yang memegang tanda bermain dan menjawab dan mendiskusikan pesan-pesan permainan simulasi

c. Pemegang peran, individu yang berperan sebagai orang-orang atau tokoh yang ada dalam skenario permainan, misalnya: guru, kepala sekolah, orang tua, tokoh masyarakat, dan sebagainya. Tugas pemegang peran adalah memberikan pendapat pada masalah yang menyangkut bidangnya untuk memperjelas informasi.

d. Penonton, yaitu mereka yang ikut menyaksikan permainan simulasi dan berhak mengemukakan pendapatnya, menjawab pertanyaan dan ikut berdiskusi

Setelah peserta permainan ditentukan, permainan dapat dilaksanakan dengan memperhatikan langkah-langkah sebagai berikut:

a. Menyediakan alat permainan beserta kelengkapannya

b. Fasilitator menjelaskan tujuan permainan. Dalam kegiatan bimbingan kelompok yang menjadi fasilitator adalah konselor, guru, atau wali kelas.

c. Menentukan pemain, pemegang peran, dan penulis.

d. Menjelaskan aturan permainan

e. Bermain dan berdiskusi

f. Menyimpulkan hasil diskusi setelah seluruh permainan selesai, dan mengemukakan masalah-masalah yang belum sempat diselesaikan saat itu.

g. Menutup permainan dan menentukan waktu dan tempat bermain berikutnya.

Ujian Nasional (UN) merupakan agenda rutin yang diselenggarakan di setiap sekolah-sekolah. Ujian Nasional merupakan salah satu cara pemerintah 
untuk meningkatkan mutu pendidikan Indonesia. Siswa harus mampu mencapai standar nilai tertentu sebagai syarat kelulusan.

Bagi siswa sendiri, adanya UN sebagai penentu kelulusan siswa dalam suatu jenjang pendidikan formal, menjadikan beban yang luar biasa, bahkan perasaan ini mungkin saja dirasakan sejak siswa menempati kelas akhir dari suatu jenjang. Siswa mengalami kecemasan jika mereka tidak mampu mencapai standar kelulusan yang telah ditetapkan (Harti, 2008).

Ujian Nasional ini menimbulkan kecemasan pada setiap siswa dikarenakan standar nilai kelulusan yang ditetapkan oleh pemerintah mengalami kenaikan setiap tahunnya, sehingga pada umumnya para pelajar mengalami kecemasan jika nilai mereka tidak memenuhi standar nilai yang telah ditetapkan.

Berdasarkan kriteria kelulusan ujian nasional dalam POS UN 2011 yang dikeluarkan oleh Badan Standar Nasional Pendidikan, poin VI: nilai US diperoleh dari gabungan antara nilai sekolah dengan bobot 60 persen dan nilai rapor dengan bobot 40 persen dari semester 1 sampai semester 5 untuk SMP sederajat dan semester 3 sampai semester 5 untuk SMA sederajat. Sedangkan NA menentukan kelulusan peserta didik dalam UN. Kriterianya dilihat dari gabungan antara nilai sekolah dari mata pelajaran yang diujinasionalkan dan nilai UN dengan pembobotan 40 persen untuk nilai sekolah untuk mata pelajaran yang di uji nasionalkan dan 60 persen untuk UN. Peserta didik dinyatakan lulus apabila nilai rata-rata dari semua NA mencapai paling rendah 5,5 dan nilai setiap mata pelajaran paling rendah 4,0 (Nurba, 2011).

\section{Penerapan Game Simulation untuk Mereduksi Kecemasan dalam Menghadapi UN}

Bermain merupakan cara belajar yang menyenangkan, karena dengan bermain anak-anak belajar sesuatu tanpa mempelajarinya. Apa yang dipelajari ini disimpan dalam pikirannya dan akan dipadukan menjadi satu kesatuan dengan pengalaman-pengalaman lain yang kadang tanpa disadarinya.

Bagi siswa, adanya UN sebagai penentu kelulusan siswa dalam suatu jenjang pendidikan formal, menjadikan beban yang luar biasa besar bagi calon peserta ujian, bahkan perasaan ini mungkin saja dirasakan sejak siswa menempati kelas akhir dari suatu jenjang. Siswa mengalami kecemasan jika mereka tidak mampu mencapai standar kelulusan yang telah ditetapkan (Harti, 2008).

Ketenangan dalam menghadapi Ujian Nasional mutlak diperlukan bagi peserta Ujian Nasional. Salah satu upaya agar mereka dapat mereduksi kecemasan yang berlebihan dengan permainan simulasi. Permainan simulasi menurut Adam (dalam Romlah: 2006) adalah permainan yang dimaksudkan untuk merefleksikan situasi-situasi yang terdapat dalam kehidupan sebenarnya. 
Berdasarkan paparan di atas peneliti mengajukan hipotesis penelitian sebagai berikut: Aplikasi game simulation efektif untuk mereduksi kecemasan dalam menghadapi UN siswa Kelas IX SMP Negeri 1 Dagangan.

\section{METODE PENELITIAN}

Metode penelitian eksperimental, yaitu suatu penelitian yang memberikan perlakuan terhadap variabel bebas. Pada penelitian ini terdapat dua kelompok perlakuan, yaitu kelompok pertama adalah kelompok yang diperlakukan dengan pengaplikasian game simulation untuk mereduksi kecemasan dalam menghadapi UN, dan kelompok kedua adalah kelompok yang diperlakukan dengan cara konvensional untuk mereduksi kecemasan dalam menghadapi UN.

Penelitian ini menggunakan desain True-Experimental Design, yaitu suatu penelitian dengan memberikan perlakuan terhadap dua kelompok subyek yang dtetapkan secara acak masing-masing kelompok diberi kondisi yang berbeda. Pratest tidak digunakan dalam disain ini; pengacakan digunakan untuk mengendalikan semua kemungknan variabel di luar serta untuk menjamin bahwa setiap perbedaan di antara kedua kelompok itu sebelum eksperimen dilakukan hanya dapat dikaitkan dengan faktor kebetulan. Penelitian ini terdiri dari dua variable, yaitu:

1. Kecemasan sebagai variable terikat $(\mathrm{X})$

2. Aplikasi Game Simulation sebagai variable bebas (Y)

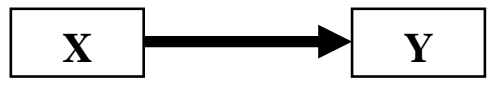

Definisi operasional:

1. Kecemasan adalah penurunan kondisi psikis atau ketakutan dalam menghadapi UN yang dialami oleh siswa kelas IX SMP N 1 Dagangan.

2. Game simulation dalam strategi permainan yang akan diterapkan untuk mereduksi kecemasan yang dialami oleh siswa kelas IX SMP N 1 Dagangan

Populasi dan penelitian ini adalah siswa kelas IX Sekolah Menengah Pertama Negeri 1 Dagangan Madiun, dengan jumlah populasi sebanyak 245 Siswa (lima kelas). Dan sampel diperoleh dari lima kelas diambil 1 (satu) kelas sebagai subyek perlakuan dengan pengaplikasian game simulation untuk mereduksi kecemasan dalam menghadapi UN, dan kelas 2 (dua) berikutnya adalah upaya mereduksi kecemasan dengan pendekatan konvensional (penasehatan), diambil secara random sampling dari lima kelas yang ada. Penelitian ini dilaksanakan di SMP Negeri 1 Dagangan Madiun. Tempat penelitian ini terdapat di Jalan Raya Dungus, Desa Banjarsari Wetan, Kecamatan Dagangan, Kabupaten Madiun. 
Data yang akan diperoleh dalam penelitian ini adalah dengan cara test, yaitu setelah diadakan perlakuan tindakan kelas. Perlakuan pada kelompok pertama adalah perlakuan terhadap subyek yang diberi perlakuan dengan pengaplikasian game simulation untuk mereduksi kecemasan dalam menghadapi UN. Perlakuan pada kelompok yang kedua adalah perlakuan terhadap subyek yang diberi pelayanan dengan konvensional. Setelah kedua kelompok diberi perlakuan, para subyek penelitian diberikan assesment, yaitu assesment untuk mengukuran kecemasan, untuk melakukan assessment peneliti mengunakan rating scale 5 skala.

Untuk menganalisis data dalam penelitian ini digunakan analisis statistika, yaitu teknik t_SCORE atau z-Score dengan rumus :

$$
\mathrm{t}=\frac{\mathrm{M}_{\mathrm{x}}-\mathrm{M}_{\mathrm{y}}}{\mathrm{SD}_{\mathrm{bM}}}
$$

$\underline{\text { Keterangan }}$

$$
\begin{array}{ll}
\mathrm{M}_{\mathrm{X}} & \text { Mean dari sampel X (pengajaran dengan pendekatan } \\
& \text { konstuktivisme) } \\
\mathrm{M}_{\mathrm{y}} & =\text { Mean dari sampel Y (pengajaran konvensional) } \\
\mathrm{SD}_{\mathrm{bM}} & =\text { Standard Kesalahan Perbedaam Mean. }
\end{array}
$$

\section{Hasil}

Dari data yang terkumpul mengenai kecemasan siswa dalam menghadapi $\mathrm{UN}$, setelah diberi perlakuan game simulation dengan sampel siswa kelas IX yang berjumlah 20 siswa diperoleh total score sebanyak 1961. Data kecemasan siswa itu diperoleh melalui pengisian rating scale, yaitu setelah siswa diberikan perlakuan game simulation untuk mereduksi kecemasan siswa dalam menghadapi $\mathrm{UN}$.

Dari data yang terkumpul mengenai kecemasan siswa dalam menghadapi UN, yang diperlakukan dengan cara pendekatan konvensional (penasehatan) dengan sampel siswa kelas IX yang berjumlah 20 siswa diperoleh total score sebanyak 1572 . Data kecemasan siswa itu diperoleh melalui pengisian rating scale, yaitu pada siswa yang diperlakukan dengan cara pendekatan konvensional (penasehatan) untuk mereduksi kecemasan siswa dalam menghadapi UN.

Uji hipotesis dilakukan dengan analisis statistik yaitu dengan t_Score atau sering dinamakan Z-Score. Hasil dari analisis adalah sebagai berikut: 
Tabel 4.1

Tabel Distribusi Hasil Rating Scale Kecemasan Siswa yang Diberi Perlakuan dan tidak Diberikan Perlakuan Game Simulation

\begin{tabular}{|c|c|c|c|c|}
\hline Subyek & $\mathrm{X} 1$ & $\mathrm{X} 2$ & $\mathrm{X} 1$ & $\mathrm{X} 2$ \\
\hline 1 & 112 & 75 & 12544 & 5625 \\
\hline 2 & 108 & 72 & 11664 & 5184 \\
\hline 3 & 112 & 74 & 12544 & 5476 \\
\hline 4 & 62 & 74 & 3844 & 5476 \\
\hline 5 & 107 & 80 & 11449 & 6400 \\
\hline 6 & 110 & 74 & 12100 & 5476 \\
\hline 7 & 99 & 86 & 9801 & 7396 \\
\hline 8 & 86 & 75 & 7396 & 5625 \\
\hline 9 & 88 & 79 & 7744 & 6241 \\
\hline 10 & 93 & 85 & 8649 & 7225 \\
\hline 11 & 114 & 73 & 12996 & 5329 \\
\hline 12 & 93 & 81 & 8649 & 6561 \\
\hline 13 & 97 & 79 & 9409 & 6241 \\
\hline 14 & 114 & 75 & 12996 & 5625 \\
\hline 15 & 66 & 86 & 4356 & 7396 \\
\hline 16 & 99 & 74 & 9801 & 5476 \\
\hline 17 & 104 & 79 & 10816 & 6241 \\
\hline 18 & 95 & 84 & 9025 & 7056 \\
\hline 19 & 102 & 81 & 10404 & 6561 \\
\hline 20 & 100 & 86 & 10000 & 7396 \\
\hline Jumlah & 1961 & 1572 & 196187 & 124006 \\
\hline Kode & $\sum \mathbf{X}_{1}$ & $\sum \mathbf{X}_{\mathbf{2}}$ & $\sum \mathbf{X}_{1}{ }^{2}$ & $\sum \mathbf{X}_{2}{ }^{2}$ \\
\hline
\end{tabular}

1. Menghitung $X_{1}$

$$
\begin{aligned}
\mathrm{X}_{1} & =\frac{\sum \mathrm{X}_{1}}{N_{X 1}} \\
& =\frac{1961}{20} \\
& =98.05
\end{aligned}
$$

2. Menghitung $X_{2}$

$$
\begin{aligned}
\mathrm{X}_{2} & =\frac{\sum \mathrm{X}_{2}}{N_{X 2}} \\
& =\frac{1572}{20} \\
& =78,6
\end{aligned}
$$


3. Menghitung $\mathrm{SD}_{\mathrm{X} 1}^{2}$

$$
\begin{aligned}
\mathrm{SD}_{\mathrm{X} 1}^{2} & =\frac{\sum X 1^{2}}{X_{1}}-M^{2} X 1 \\
& =\frac{196187}{20}-98.05^{2} \\
& =9809,35-9613,8 \\
& =195,55
\end{aligned}
$$

4. Menghitung $\mathrm{SD}^{2} \mathrm{X} 2$

$$
\begin{aligned}
\mathrm{SD}_{\mathrm{X} 2}^{2} & =\frac{\sum X 2^{2}}{X_{2}}-M^{2} X 2 \\
& =\frac{124006}{20}-78,6^{2} \\
& =6200,3-6177,96 \\
& =22,34
\end{aligned}
$$

5. Menghitung $\mathrm{SD}^{2}{ }_{\mathrm{Mx}}$

$$
\begin{aligned}
\mathrm{SD}_{\mathrm{Mx} 1}^{2} & =\frac{\mathrm{SD}_{\mathrm{X} 1}^{2}}{\mathrm{Nx} 1-1} \\
& =\frac{195,55}{20-1} \\
& =10,29
\end{aligned}
$$

6. Menghitung $\mathrm{SD}_{\mathrm{Mx} 2}^{2}$

$$
\begin{aligned}
\mathrm{SD}_{\mathrm{Mx} 2}^{2} & =\frac{\mathrm{SD}_{\mathrm{X} 2}^{2}}{\mathrm{Nx} 2-1} \\
& =\frac{22,34}{20-1} \\
& =1,18
\end{aligned}
$$

7. Menghitung $\mathrm{SD}_{\mathrm{Bm}}$

$$
\begin{aligned}
\mathrm{SD}_{\mathrm{bM}} & =\sqrt{\mathrm{SD} 2 \mathrm{Mx} 1-\mathrm{SD} 2 \mathrm{Mx} 2} \\
& =\sqrt{10,29-1,18} \\
& =\sqrt{9,11} \\
& =3,02
\end{aligned}
$$

8. Menghitung t-Score

$$
\begin{aligned}
\mathrm{t} \quad & =\frac{M_{x 1}-M_{x 2}}{S D_{b M}} \\
& =\frac{98.05-78,6}{3,02} \\
& =6,44
\end{aligned}
$$


9. Menentukan besarnya t dalam tabel.

Dengan sampel 40 siswa didapatkan harga tabel dengan d.b N - 2 (40 - 2), pada taraf kepercayaan $95 \%$ didapatkan angka t dalam tabel sebesar 2,021 dan pada taraf kepercayaan $99 \%$ didapatkan angka 2,704

\section{Penafsiran Hasil Analisis Data}

Dengan t-score sebesar 6,44, apabila dibandingkan dengan $t$-table pada taraf kepercayaan $95 \%$ ternyata $t$-score atau t-hitung lebih besar, sehingga hipotesis nol ditolak. Dengan demikian hipotesis yang menyatakan ada perbedaan yang signifikan antara kecemasan siswa yang diberi perlakuan game simulation dan yang diberi perlakuan dengan pendekatan konvensional pada siswa SMP Negeri I Dagangan Madiun diterima. Begitu juga pada taraf kepercayaan 99\% ternyata tscore atau t hitung lebih besar, sehingga hipotesis nol ditolak. Dengan demikian hipotesis yang menyatakan ada perbedaan yang signifikan antara kecemasan siswa yang diberi perlakuan game simulation dan yang diberi perlakuan dengan pendekatan konvensional pada siswa SMP Negeri I Dagangan Madiun diterima. Hal ini berarti hipotesis penelitian yang diajukan ada perbedaan yang signifikan baik dalam taraf kepercayaan $95 \%$ maupun $99 \%$. Dari hasil pengujian data dapat ditarik sebuah kesimpulan penelitian ini menunjukkan bahwa game simulation berpengaruh positif dalam mereduksi kecemasan siswa dalam menghadapi UN, baik dalam taraf $95 \%$ maupun $99 \%$.

\section{Simpulan}

Sesuai dengan permasalahan yang diteliti dan prosedur yang ditempuh, penelitian ini menggunakan desain True-Experimental. Sampel penelitian ditetapkan secara acak yang keseluruhannya berjumlah 40 siswa SMP Negeri I Dagangan Madiun dengan perincian 20 siswa untuk kelompok yang diberi perlakuan game simulation untuk mereduksi kecemasan dalam menghadapi UN dan 20 siswa untuk kelompok yang diberi perlakuan dengan pendekatan konvensional untuk mereduksi kecemasan dalam mengahadapi UN.

Pelaksanaan eksperimental berlangsung selama 10 kali masing-masing berjalan selama 45 menit di lapangan. Data yang berhasil dikumpulkan melalui 
assesment, dianalisis dengan t-test. Hasil analisis data menunjukkan bahwa penelitian mengenai perbedaan kecemasan siswa dalam menghadapi UN antara yang diberi perlakuan dengan game simulation dan yang diberi perlakuan dengan pendekatan konvensional dalam taraf kepercayaan $95 \%$ terbukti secara signifikan. Begitu pula pada taraf kepercayaan $99 \%$ terbukti ada perbedaan yang signifikan.

Dari kedua perbedaan tersebut di atas, diperoleh score total berdasarkan rating scale pada siswa yang diberi perlakuan game simulation sebesar 1961. Sedangkan score total hasil pengisian rating scale pada siswa yang diberi perlakuan dengan pendekatan konvensional sebesar 1572. Berdasar perhitungan tscore diketahui ada perbedaan sebesar rata-rata 6,44 antara kedua kelompok tersebut. Hal ini menunjukkan bahwa game simulation berpengaruh positif dalam mereduksi kecemasan siswa dalam menghadapi UN, baik dalam taraf $95 \%$ maupun $99 \%$.

Dari hasil penelitian ini dapat diberikan saran-saran sebagai berikut: 1 . Diharapkan guru mampu memilih strategi dengan tepat dalam mengurangi kecemasan, sehingga hasil belajar siswa dapat tercapai secara maksimal sesuai dengan kemampuan dasar yang diharapkan. Salah satu strategi adalah game simulation; 2. Kepada siswa disarankan, di dalam menghadapi UN harus memerlukan persiapan yang matang dan meminimalisir kecemasan. Jangan sampai kecemasan yang terjadi pada diri siswa menjadi boomerang bagi diri siswa sendiri; 3. Baik siswa maupun guru disarankan menjalankan fungsi dan peranannya masing-masing secara aktif dan kreatif; 4. Konselor sekolah, hasil penelitian ini bisa dijadikan pertimbangan untuk memperkaya layanan konseling, dan tentunya mampu mengaplikasikan game simulation ini untuk mereduksi kecemasan siswa dalam menghadapi UN untuk tahun ajaran berikutnya; 5 . Kepada kepala sekolah, diharapkan dapat memberikan motivasi kepada guru dan siswa dalam meningkatkan kreativitasnya dan tidak perlu cemas dalam menghadapi UN. 


\section{DAFTAR PUSTAKA}

Emzir. 2010. Metodologi Penelitian Pendidikan Kuantitatif dan Kualitatif. Jakarta: Rajawali pers

Harti, Y. (2008). Masih Perlukah Ujian Nasional?. Guru Valah. Diaskes pada tanggal 30 Desember 2012 dari http: //www. guruvalah. 20m. com/kontoversi_ujian_nasional. html.

Marco, Denny. 2012. Empat Tingkat Kecemasan. Diakses Pada tanggal 06 Februari 2013 dari http://dmarco.mywapblog.com/empat-tingkatkecemasan.xhtml

Nevid, dkk. 2003. Psikologi Abnormal. Jakarta: Erlangga

Ramaiah, S. 2003. Bagaimana Mengatasi Penyebabnya. Jakarta: Yayasan Obor Indonesia.

Romlah, Tatiek. 2006. Teori dan Praktek Bimbingan Kelompok. Malang: Universitas Negeri Malang

Arikunto, Suharsimi, (2002). Prosedur Penelitian, Suatu Pendekatan Praktek. Jakarta: PT. Rineka Cipta.

Wiramihardja, A, Sutardjo. 2007. Pengantar Psikologi Abnormal. Bandung :

Refika Aditama 